\title{
Policies and Socio-economics Influencing on Agricultural Production: A Case Study on Maize Production in Bokeo Province, Laos
}

\author{
Southavilay Boundeth ${ }^{1}$, Teruaki Nanseki ${ }^{2} \&$ Shigeyoshi Takeuchi ${ }^{2}$ \\ ${ }^{1}$ Graduate school of Bioresource and Bioenvironmental Science, Laboratory of Agricultural and Farm \\ Management, Department of Agricultural and Resources Economics, Kyushu University, Japan \\ ${ }^{2}$ Faculty of Agriculture, Kyushu University, Japan \\ Corresponding author: Teruaki Nanseki, Faculty of Agriculture, Kyushu University, Japan. Tel: 81-926-422-970. \\ E-mail: nanseki@agr.kyushu-u.ac.jp
}

Received: August 17, 2012 Accepted: October 10, 2012 Online Published: October 25, 2012

doi:10.5539/ sar.v2nlp70

URL: http://dx.doi.org/10.5539/sar.v2nlp70

\begin{abstract}
Since 2005s, agricultural land in northern Laos has become to be dominated by maize mono-cropping. The rapid expansion of this commercial crop has the resulted of policy implementations and demand of maize from the neighboring countries. The purpose of this study was aim to analyze the impact of commercial agricultural policy and socio-economic factors influencing on maize production in Houyxai Distirct, Bokeo Province of Laos. A survey of 98 maize farmers by face to face interviews was conducted in September 2010. Ordinary Least Square regression model was applied in order to explain how these policies and socio-economic factors effect to farmers and contribute to maize production. The results revealed that $94 \%$ of the variation in maize production (ton) is explained by the selected explanatory variables. Seven variables have a positive significant and one variable has a negative effect on maize production volume. The results also demonstrated thatthe most important effect to maize production is a "policy push" mainly variables of farmland, farmer organization, support market and credit access and a "market pull" by private sectors with providing input factors namely seeds, land preparation and techniques. Therefore, the government should look at the way of credit providing system that may effect in high production cost, at the same time the expansion of farm size is needed to take into account.
\end{abstract}

Keywords: maize famers, productivity, production group, ordinary least square, Laos

\section{Introduction}

In 2005, Lao government introduced the new policy called Commercialization of Agriculture and Commodity Production (Southavilay et al., 2012). The policy aimed at reducing poverty in the rural areas by transforming upland agriculture from traditional shifting cultivation to market oriented production. The shifting cultivation appears to have been overtaken by mixed annuals and permanent farms. Annual crops include maize and other cash crops (soybeans, peanuts, watermelon and banana), and permanent farms include fruit trees, rubber and teak. According to Southavilay et al. (2012), an annual crop as the maize was considered as one of cash crops for commercial production to boost rural livelihoods and reduce the area of shifting cultivation. As the results, from 2005 to 2009 , the maize production was sharply increased from 372500 tons to 1120875 tons respectively and reduced to 1020875 tons in 2010 (MAF, 2010).

However, among surveyed households, both upland and lowland farmers includes group members and non-group members, have in general an average of 1.57 ha of maize cultivation land and a received productivity (yields) an average of 5.78 tons/ha, and greater than the national average of maize yields as $4.8 \mathrm{t} / \mathrm{h}$ (DOP, 2010). A reason is that there were several factors influencing such as has fertile soils in the upland farm and also an appropriate location for lowland farm. The lowland farms are usually located along the river flood plains with appropriate to cultivate perennial crops (Southavilay et al., 2012).

In order to meet the commercial agricultural production 'spolicy, various areas throughout the country have been implemented the tools as stated in the $6^{\text {th }}$ National Socio-economic Development Program (NSEDP) aimed to facilitate marketing and strengthen bargaining powers of farmers through the production groups. The policy in the $6^{\text {th }}$ NSEDP has also encouraged the private enterprises including foreign investors and traders from both domestic and neighboring countries to invest agribusiness mainly market and credit accesses, this is a "market pull".

In Laos, producing groups are gradually being developed and introduced to support farmers who are facing an agricultural productivity, poor bargaining power and problems to meet buyers' quality requirements. For instance, 
the Maize Production Groups (MPGs) in Bokeo province has been implemented. These groups are the one of farmer organizations as the Lao government considers as basic tools to transform subsistence to oriented market agricultural production.

In 2006, the MPG was established by the government as the Provincial Agriculture and Forestry Office (PAFO) in Bokeo province. This organization was acceptable by maize farmers (Southavilay et al, 2010). As the result, in 2009, there were 26 groups of MPGs from 207 villages, accounted to 50\% of the total villagers in the Bokeo province were established. The group member includes of 11410 families with their maize cultivated area of 14 401 ha in 2009 (PAFO, 2010). According to, the government has identified farmer group as a basic framework for increasing production volume (NAFRI, 2011). The function of farmer group is mainly to increase production volume with providing marketing systems, processing services, credit and introduce a new technology. Consequently, it is expected that the policies on farm organization, market and credit access play a significant role in enhancing farmer intensity of input use and influences the maize farmer to increase production volume. Therefore, the objectives of this study are thus to analyze the impact of policies (farmer group, market and credit access) and other socio-economic characteristics on maize production volume.

\section{Study Site}

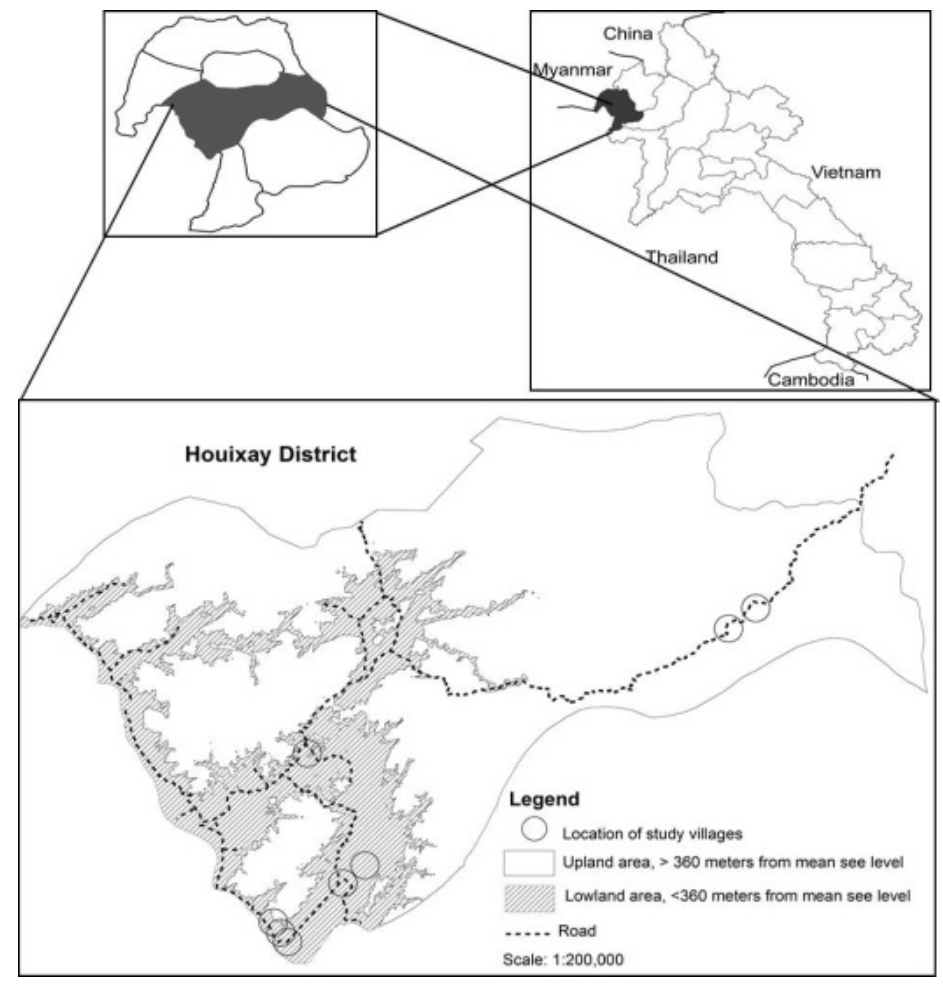

Figure1. Map of the Study Site

Figure1 shows the location of the study area which located in Bokeo province in the northern Laos. The province is mountainous and bordering Myanmar and Thailand. It has a total land area of $6196 \mathrm{~km}^{2}$ and with a population of about 157500 people, and most of them live in small rural areas and practice agriculture (Southavilay et al., 2012). In this province, the maize production was one of main commercial crops to boost local economics. The maize harvested area had sharply increased during last 10 years, from 1600 ha in 2000 to 21000 ha in 2010 (PAFO, 2010).

\section{Data and Methods}

The data used in this study mainly based on primary data which conducted from maize farmers in Houixay District, Bokeo provincein September 2010. Face to face interviews were conducted from a total of 98 maize farmers in 8 villages. There are 64 farmers in this sample who are group members and 34 farmers are non-members. The structure of questionnaires has included the household and farm information. 
Table1. Summary statistics of output and input variables included in the OLS model

\begin{tabular}{|c|c|c|c|c|c|}
\hline Variable & Description & Max & Min & Average & SD \\
\hline Output (Y) & Maize production (tons) & 40.0 & 1.0 & 8.8 & 7.1 \\
\hline Farmsize $\left(\mathrm{X}_{1}\right)$ & Maize farmland (ha) & 7.0 & 0.3 & 1.5 & 1.0 \\
\hline Seeds $\left(X_{2}\right)$ & Total amout of seeds $(\mathrm{kg})$ & 100.0 & 9.0 & 28.5 & 16.4 \\
\hline Fertilizer $\left(\mathrm{X}_{3}\right)$ & Total amount of fertilizer $(\mathrm{kg})$ & $1,100.0$ & 25.0 & 218.6 & 226.1 \\
\hline Labor $\left(\mathrm{X}_{4}\right)$ & $\begin{array}{l}\text { Total hired workers used in maize } \\
\text { production (Man-day) }\end{array}$ & 207.9 & 10.0 & 62.3 & 39.4 \\
\hline Experience $\left(\mathrm{X}_{5}\right)$ & Experience in maize cultivation (years) & 20.0 & 1.1 & 9.7 & 5.7 \\
\hline Age $\left(\mathrm{X}_{6}\right)$ & Age of head household (years) & 70.0 & 27.0 & 46.0 & 9.9 \\
\hline Household size $\left(X_{7}\right)$ & Household member (persons) & 9.0 & 3.0 & 4.7 & 1.4 \\
\hline Education $\left(\mathrm{X}_{8}\right)$ & Farmer's education (years) & 15.0 & 0.0 & 5.8 & 3.2 \\
\hline Membership $\left(\mathrm{X}_{9}\right)$ & $\begin{array}{l}\text { Dummy variable which takes the value of } 1 \\
\text { if the farmers is group membership; } 0=\text { not } \\
\text { a member }\end{array}$ & 1.0 & 0.0 & 0.6 & 0.5 \\
\hline Seed variety $\left(\mathrm{X}_{10}\right)$ & $\begin{array}{l}\text { Dummy variable which takes the value of } 1 \\
\text { if farmer used hybrid seeds; } 0=\text { do not use }\end{array}$ & 1.0 & 0.0 & 0.5 & 0.5 \\
\hline Machine $\left(\mathrm{X}_{11}\right)$ & $\begin{array}{l}\text { Dummy variable which takes the value of } 1 \\
\text { if farmers use a machine for cultivating; } 0= \\
\text { do not use }\end{array}$ & 1.0 & 0.0 & 0.7 & 0.5 \\
\hline Market access $\left(\mathrm{X}_{12}\right)$ & $\begin{array}{l}\text { Dummy avriable which takes the value of } 1 \\
\text { if market access to the village; } 0=\text { not }\end{array}$ & 1.0 & 0.0 & 0.7 & 0.5 \\
\hline Credit access $\left(\mathrm{X}_{13}\right)$ & $\begin{array}{l}\text { Dummy avriable which takes the value of } 1 \\
\text { if farmer access to credit; } 0=\text { not }\end{array}$ & 1.0 & 0.0 & 0.5 & 0.5 \\
\hline
\end{tabular}

Source: Data Survey, 2010.

Table 1 shows the summary statistics of output and inputs variables. The data on farm information included quantity of maize products, farm size, labor, amount fertilizer usage, seed usage, seed variety and machinery. The household information or socio-economic data of the farmers including farming experiences, farmer`s age, level of education, household size, source of credit, market access and membership.

An Ordinary Least Squares (OLS) regression model was applied to analyze factors influencing in maize production. This model would be able to identify the effect of policies and difference of socio-economic factors of each household on maize production. There were many researchers used the socio-economic variables to study the influence of different factors on the behavior of a specific group of people (Fusun Tathdil, Boz, \& Tatlidi, 2009). In addition, socio-demographic variables (gender, age, education and etc.) are usually influenced on farm activities (Angie et al., 2012). The econometric model used to analyze the determinant of maize production is as show in equation (1).

$$
y_{\mathrm{i}}=a_{i}+b_{j} X_{i j}+\mu_{i}
$$

Where $y_{i}$ is the output of $\mathrm{i}^{\text {th }}$ farmer in tons; $a_{i}$ is the intercept; $X_{i}$ is a vector of household factors that potentially explain the maize production and $\mu_{i}$ is a random error term $(\mathrm{j}=1 \sim 13)$ as showed in Table 1 .

\section{Results and Discussions}

An OLS model was used to measure the commercial agricultural policies and other socio-economic factors which have a positive or negative effect on the maize production. A correlation matrix was applied to assess for the presence of collinearity between the independent variables used in each model (Angie et al., 2012). The results of correlation matrix test among each independent variable are not highly correlated. It means that low potential biases in the model estimation. 
Table2. The OLS regression function estimation outputs

\begin{tabular}{lcccccc}
\hline \multicolumn{1}{c}{ Model } & Unstandardized Coefficients & $\begin{array}{c}\text { Standardized } \\
\text { Coefficients }\end{array}$ & $\mathrm{t}$ & 95\% Confidence Interval for B \\
& $\mathrm{B}$ & Std. Error & Beta & & Lower Bound & Upper Bound \\
\hline (Constant) & $.354 * * * *$ & 1.976 & & 5.179 & 4.284 & 5.576 \\
Farm size $\left(\mathrm{X}_{1}\right)$ & $6.482 * * *$ & .247 & .905 & 26.194 & 5.990 & 6.974 \\
Seeds $\left(\mathrm{X}_{2}\right)$ & $.033 * * *$ & .063 & .022 & 2.522 & -.092 & .158 \\
Fertilizer $\left(\mathrm{X}_{3}\right)$ & $-.073 *$ & .003 & -.012 & -1.794 & -.007 & .005 \\
Labor $\left(\mathrm{X}_{4}\right)$ & $.006 *$ & .010 & .034 & 1.699 & -.014 & .026 \\
Experiences $\left(\mathrm{X}_{5}\right)$ & $.069 * *$ & .062 & .056 & 1.704 & -.055 & .193 \\
Age $\left(\mathrm{X}_{6}\right)$ & .006 & .021 & .008 & .270 & -.035 & .047 \\
Household size $\left(\mathrm{X}_{7}\right)$ & -.190 & .163 & -.037 & -1.163 & -.514 & .135 \\
Education $\left(\mathrm{X}_{8}\right)$ & -.098 & .066 & -.045 & -1.484 & -.229 & .033 \\
Membership $\left(\mathrm{X}_{9}\right)$ & $.309 * * *$ & .579 & .022 & 2.534 & -.842 & 1.460 \\
Seed variety $\left(\mathrm{X}_{10}\right)$ & -.495 & .634 & -.035 & -.780 & -1.756 & .766 \\
Machine $\left(\mathrm{X}_{11}\right)$ & -.536 & .881 & -.035 & -.608 & -2.287 & 1.216 \\
Market access $\left(\mathrm{X}_{12}\right)$ & $1.325 * *$ & .633 & .087 & 2.094 & .067 & 2.584 \\
Credit access $\left(\mathrm{X}_{13}\right)$ & $1.568 * * *$ & .605 & .183 & 4.244 & .772 & 2.365
\end{tabular}

Dependent Variable: Maize production (ton); Notes: $*, * *, * * *$ Significant at $10 \%, 5 \%$ and $1 \%$ confidence, respectively; Number of sample $=98, \mathrm{R}^{2}=0.940$; Adjusted $\mathrm{R}^{2}=0.930$.

Source: Survey data, 2010 with calculated by OLS model

Table 2 shows the results of OLS regression examining as described in the model (equation 1) for the 98 maize growing farmers. Identification of the socio-economic characteristics of maize production is useful not only for better understand relationship between the socio-economic drivers and maize production but also helps to formulate better strategies and appropriate policies for addressing the issue on maize production (Southavilay et al., 2012).

The overall measure of goodness of fit model is given by the $\mathrm{R}^{2}$ value. The $\mathrm{R}^{2}$ of 1.0 indicates that the regression line perfectly fits the data. In this study, the $\mathrm{R}^{2}$ value is 0.94 . This is an indication that $94 \%$ of the variation in maize production (ton) is explained by the selected of 13 explanatory variables (Table 1). From the regression result, there are seven variables has a positive significant and one variable has a negative significant effect on maize production volume.

The coefficient of farm size variable has a positive sign and was statistically significant at $1 \%$ level. This implies that if the maize cultivation area is expanded by one unit, holding other factors fixed, the total maize production volume is estimated to rise by approximately by a factor of 6.482 . This could be explained that maize production increase as a result of the expansion of the area under cultivation. This finding contradicted with the work of Vanisaveth et al (2012) indicated that farmers with large farm size of maize cultivation have many field plots and each point needs careful management. Therefore, small farm size tends to be more efficient in production than large farm size. According to the field survey, when farmers need to increase the maize production volume, the increasing farm size is usually prioritized than increasing yield. Thus, forest area is one of the most practical options for farmers to expand their farm size to larger size.

The coefficient on amount of seed use, group membership and credit access has a significant and positive effect on maize production at $1 \%$ level. The coefficient of seed amount variable has expected to have a positive value of 0.033. This implies that many maize farmers in the study area are using seeds per hectare is efficient to the output. From field survey found that the average of seed use was about $20.5 \mathrm{~kg} / \mathrm{ha}$, and this amount is an acceptable by national recommendation. The coefficient of the variable on membership in maize production group was positive as expected. A reason is because a farmer who is the group member was facilitated access to credit and market, and also provided of some techniques on farming practices. Moreover, membership was also conferred better opportunities to receive price guarantee and input factors from the group committees than non-group members. In addition, the membership is also provided on variety of agricultural training topics by extension staff and among members. Thus, farm organization is important in order to motivate farmers to grow maize. This finding is the 
same work with Angie et al. (2012) concluded that farmers who belongs to group member they can learn more techniques in order to improve their knowledge and their living standard.

For significance at $1 \%$ level of credit variable, implying that access to credit is likely to have more maize products. This implies that if the credit access is increased by one unit, holding other factors fixed, the total maize production volume is estimated to rise by approximately of 1.586 units. According to field survey we found that there were many maize farmers received credit from private sectors (traders). The credit includes cash and in-kind mainly hybrid seeds, fertilizers and also land preparation. Thus, credit access is a significant factor to increase maize production in the study area.

The coefficient of labor variable in the maize production (man-day) has a significant and positive effect on maize production at $10 \%$ level. Implying that a unit increase in the labor will increase the maize production volume by a factor of 0.006 . This is expected because most of the maize production in Laos relies heavily on labor usage, particularly during clearing field, planting, weeding and harvesting. This is the line with finding of Khamphou et al (2006) who studied the production and market conditions of Maize in Northern Laos. The variable of labor is one of important factors that effected on maize production volume. As according to filed survey showed that when the price of labor per day increased the member of maize farmers had turned to grow other crops instead of maize. According to the previous studied found that the figure of maize products in the study area has been declined about 50\% lower than its peak of 2008 (170,000 tons) when the prices were booming (Southavilay et al., 2011). This is because since government of Laos has fully opened for Chinese investors come to this region (north) for rubber plantations and cash crop production. The price of labor had significantly increased threefold, while the maize price is not much higher. For example in 2005 the labor cost was US\$1.8/day, while it is now US\$6/day (PAFO, 2012).

The variable of experiences and market access has a significant and positive effect on maize production at $5 \%$ level. It means that farmers with more years of maize farming experiences tend to be more efficient in maize production. Indicating that there is a time effect operating in maize production, with increased years of growing maize knowledge accumulates through the training, learning by doing and sharing techniques among farming for example, managing post-harvest technique for controlling moisture content, soil preparation, fertility and also control of weeds and diseases. For the market access, indicating that a unit increase in the market access will increase the maize production volume by a factor of 1.325 .

The coefficients on age, household size, education, seed variety and machinery were not significant. The variable education level had negative sign effect on maize production volume. One possible explanation for this is that the sample farmers mainly have only obtained an elementary school education level. On the other hand, the maize production in the study area was directly affected from pushed and pulled by policy and markets. Therefore, the education level does not affect to maize production in the study area.

Likewise, variables fertilizer had significance but negative effect to the maize production at $10 \%$ level. The negative sign of fertilizer can be explained that fertilizer does effect to reduce the maize production volume. This implies that a unit increase in the fertilizer usage will decrease maize production volume by a factor of 0.073 . Implying that farmers reduced the production level to avoid high production cost from fertilizers. Moreover, due to more than $38 \%$ of farmers in the study area did not apply fertilizer for maize production (Southavilay et al., 2012). These reasons might be able to explain why the fertilizer did not effect on maize production in the study area.

\section{Conclusions}

This study investigated the agricultural commercial policies and socio-economic characteristics influencing maize production volume. The results are found that some socio-economic factors such as farm size, amount of seed use, fertilizer, labor, maize farming experiences, group membership, credit and market access were statistically significant to be effective on maize production. This implies that if any one of these factors were changed (increased/decreased), it could be effect on maize production volume. Results also demonstrated that the increasing of maize production is more likely depending on farm size, amount of seed use, group membership and credit access. Conversely, maize production will be decreased when the price of fertilizer increase. It means that maize farmers will grow other crops instead of growing maize.

According to the results, we concluded that the motivation and incentive of maize production in the study area were not directly decided by farmers but mainly from other factors such as policy implanting and marketing. Moreover, many interviewed farmers also do not practice only maize but they also have other agricultural production mainly rice and livestock. In closing, the main factors behind the maize production are mainly farm size due to expanding the new farmland is still available for farmers who want to growing maize. For the amount of seeds, farmer organization and credit access is another very important factor for increasing volume of maize production. The other factors to contribute maize production were included market accesses, experiences and 
labors. Those factors are the result of a "policy push" and "policy pull" aimed at reducing poverty, stabilizing farming systems and encouraging private sectors to invest in agriculture with providing inputs namely seeds, land preparation, techniques, market and credit access. Therefore, the government should emphasizes on those factors, especially by looking at the way of credit providing and marketing system that may affect to maize farmers in high production cost, at the same time the expansion of farm size is needed to take into account.

\section{Acknowledgement}

We are grateful to the staff of Bokeo provincial agriculture and forestry office for their help during fieldwork and other assistances. This research was supported by Japanese Government through MEXT scholarship. We gratefully acknowledge to this support.

\section{References}

Angie, H., Moritaka, M., \& Fukuda, S. (2012). The Impact of Socio-Economic Characteristics on Coffee Farmers` Marketing Channel Choice: Evidence from Villa Rica, Peru. Journal of Sustainable Agriculture Research, 1(1), 13-18.

DOP (Department of Planning). (2010). Yearly Report of Ministry of Agriculture and Forestry.Vientiane Capital, Laos.

Fusan Tathdil, F., Boz, I., \& Tathlidil, H. (2009). Farmers Perception of Sustainable Agriculture and Its Determinants: A Case Study in Kahramanmara Province of Turkey. Journal of Environment, Development and Sustainable, 11(6), 1091-1106. http://dx.doi.org/10.1007/s10668-008-9168-x

Khampou, P., \& Daniel, T. (2006). Case Study on Production and Market Conditions for Corn in Namor District, Oudomxay Province, Progress Report, Laos.

NAFRI (National Agriculture and Forestry Research Institute). (2011). Beyond Production: Facilitating Market Access through Farmer Group, Vientiane, Laos.

PAFO (Provincial Agriculture and Forestry Office). (2010). Annual Report, Bokeo Province, Laos.

PAFO (Provincial Agriculture and Forestry Office). (2012). A Quarterly Report, Bokeo Province, Laos.

Southavilay, B., Nanseki, T., \& Hotta, K. (2010). Farm Organization in Maize Commodity Chain in Laos. Japanese Journal of Farm Management, 49(2), 170-175.

Southavilay, B., Nanseki, T., \& Takeuchi, S. (2012). Study of Farmers' Perception and Socio-economic Determinants on Land Degradation in Northern Laos: ACase Study of Maize Production. European Journal of Social-Sciences, 28(4), 502-511.

Vanisaveth, V., YABE, M., \& SATO, G. (2012). Analysis of Technical Efficiency of Smallholder Maize Farmers in Northern Laos: Case Study of Paklay District, Sayaboury Province. Journal of the Faculty of Agriculture, Kyushu University, 57(1), 309-315. 